\title{
Destruction of secondary Schistosoma mansoni sporocysts in Biomphalaria glabrata after phytochemical exposure
}

\section{Gabriela Friani}

Universidade Federal Rural do Rio de Janeiro

\section{Valdir Almeida da Costa}

Fundacao Oswaldo Cruz

\section{Ester Mota}

Fundacao Oswaldo Cruz

\section{Marta Julia Faro}

Fundação Oswaldo Cruz

\section{Samaly Souza}

Centers for Disease Control and Prevention

\section{Marcela Figueiredo}

Fundacao Oswaldo Cruz

\section{Patricia Golo}

Universidade Federal Rural do Rio de Janeiro

Clélia Christina Mello-Silva ( $\sim$ clelia@ioc.fiocruz.br)

Instituto Oswaldo Cruz https://orcid.org/0000-0002-5575-2272

\section{Short report}

Keywords: Biomphalaria glabrata, Euphorbia milii, hemocytes, phytochemical, susceptibility

Posted Date: April 6th, 2020

DOI: https://doi.org/10.21203/rs.3.rs-20755/v1

License: (1) (1) This work is licensed under a Creative Commons Attribution 4.0 International License. Read Full License 


\section{Abstract}

Background: Schistosomiasis is a neglected tropical disease and affects over 200 million people worldwide. The snail Biomphalaria glabrata is one of the intermediate hosts of S. mansoni . The aim of this work was to verify the action of Euphorbia milii var. hislopii latex in the hemocytes profile and histopathology of B. glabrata infected by S. mansoni .

Methods: Uninfected and infected snails were exposed to sublethal concentrations of E. milii latex for 24 hours $(1.0 \mathrm{mg} / \mathrm{l}$ less than the LC 50 ) and after this time were analysed.

Results: The survival rate was $88.5 \%$ for the uninfected snails and $66.6 \%$ for the infected and exposed snails. In the snails infected by S. mansoni , the exposure to E. milii latex promoted proliferation of hemocytes in the tentacles, mantle, digestive gland, kidney and ovotestis. In the digestive gland and the kidney, granulomatous reactions occurred around the sporocysts and caused their destruction. Proliferation of hemocytes in the kidney and digestive gland and edema in the mantle area were also observed in the uninfected and exposed snails. The number of circulating hemocytes from the group infected and exposed to E. milii latex was significantly higher than in the other groups. Three types of hemocytes were found: hyalinocytes, granulocytes and blast-like cells, and in all the groups the proportion of hyalinocytes was higher than the other types. There was no significant difference among the cell types and the different groups analyzed.

Conclusions: We conclude that the sublethal concentration of E. milii latex influenced the cellular immune response of the susceptible B. glabrata strain to infection by S. mansoni , promoting the destruction of parasites.

\section{Background}

Biomphalaria glabrata is the main intermediate host of Schistosoma mansoni [1, 2], the causative agent of schistosomiasis mansoni, affecting around 200 million people worldwide and causing up to 260,000 deaths per year $[3,4]$. In Brazil, intestinal schistosomiasis is largely associated with environmental variables and/or social determinants, infecting approximately 8 to 10 million people every year, while 25 million who live in endemic areas are at risk of infection [5].

The interaction between S. mansoni and B. glabrata starts when the free-living forms (miracidia) infect the snails and become sporocysts, the longer-term asexual parasitic stage. The success or failure of infection is determined by the balance between the snail's internal defense system (IDS) and the infective mechanism of trematode [6]. To establish an infection, the miracidia must be recognized as self, so that the carbohydrates present on the their tegument bind to the lectins on the surface of the hemocytes or vice versa, and/or free lectins in the hemolymph form bridges with the carbohydrates present on the surface of the hemocytes and larvae. If the larvae are recognized as non-self, several mechanisms of the snail's humoral and cellular responses work together to neutralize the non-self particles, especially pathogenic microorganisms $[7,8]$. 
The hemocytes are snails' defense cells acting on the cellular response mechanism. They have variable size and enzymatic content composed by at least three cell populations, hyalinocytes (cells without granularity), granulocytes (cells with high granularity) and blast-like cells (smaller size, called young cells or precursor cells of other hemocytes) [9]. The role of snail hemocytes in the recognition, killing and elimination of invading pathogens is described in several works $[10,11]$. The humoral responses include synthesis of antimicrobial peptides, cytotoxic molecules, reactive intermediates of oxygen and nitrogen and pathogen recognition receptors (PRRs) $[12,13]$. Hence, the complex nature of the snail hemocyte defense response to $S$. mansoni larvae, outlined above, makes analysis of snails exposed to molluscicides a vital component of research aimed at elucidating the array of underlying mechanisms of snail-schistosome compatibility to develop field control strategies.

One strategy to control Biomphalaria sp. in the field is the use of molluscicides, recommended by the World Health Organization (WHO). The use of natural products is encouraged by the same organization, and in this respect phytochemicals from Euphorbia milii var. hislopii have been studied the most. Many authors have described the effects of E. milii latex on the S. mansoni/B. glabrata system $[14,15]$. Other studies have shown that the application of substances derived from E. milii in water bodies in transmission areas leads to changes in physiological stocks and S. mansoni/B. glabrata compatibility [16-18]. The effects of E. milii latex on the parasite life cycle in both schistosomiasis hosts (snails and mammals) have been described. These effects include reduction of the number of miracidia and cercariae in water bodies, helping control schistosomiasis transmission in endemic areas [19]. This strategy is inexpensive, ecological, efficient and may help control in association with current anthelmintic therapy.

\section{Methods}

This study was approved by the animal experimentation ethics committee of Oswaldo Cruz Foundation (CEUA - Fiocruz L016/2015), in accordance with the guidelines of the Brazilian Society of Laboratory Animal Science (COBEA). The study was registered with the National System for Management of Genetic Heritage and Associated Traditional Knowledge (SisGen) under number A9666E5.

To obtain the latex of Euphorbia milii var. hislopii, samples of the plant were collected in the llha do Governador district $\left(22^{\circ} 48 \times 09^{\prime \prime} \mathrm{S} / 43^{\circ} 12 \times 35^{\prime \prime} \mathrm{W}\right)$ of Rio de Janeiro, Brazil. The latex was collected as described by Vasconcellos and Amorin [20]. The B. glabrata snails (Belo Horizonte, BH lineage) were obtained from the Schistosomiasis Laboratory of Fiocruz (DCB/ENSP/Fiocruz). The specimens were hatched and reared in laboratory conditions according to the Technical Guidelines on Surveillance and Control of Snails of Epidemiological Importance from the Brazilian Ministry of Health [21]. Four hundred specimens of B. glabrata were used, with shell diameters of 8 to $12 \mathrm{~mm}$. The life cycle of S. mansoni was maintained in the Laboratory for Evaluation and Promotion of Environmental Health (LAPSA/IOC/Fiocruz), where all the experiments were performed. S. mansoni miracidia were obtained from experimental infection in Swiss mice according to the technique described by Fernandez and Thiengo [22]. Each snail was infected with 8-10 miracidia of S. mansoni. One hundred and ten infected 
S. mansoni cercariae-shedding snails were used in the experiment. To verify S. mansoni infection, the snails were previously exposed to light for 60 minutes, where those that shed cercariae were considered infected. Only the positive snails (cercariae shedding) were exposed to E. milii latex.

For experimental design, four snail groups with 100 specimens each were used: Group IE- "S. mansoniinfected and exposed to E. milii latex"; Group E- "uninfected and exposed to E. milii"; Group I- "S. mansoniinfected and unexposed"; and Group C- (control) "uninfected and unexposed".

The snails of the IE and E groups were exposed to sublethal concentrations of E. milii latex $(1.0 \mathrm{mg} / \mathrm{l}$ less than the $\mathrm{LC}_{50}$ ) for 24 hours. Three replicates of the experiment were performed.

The lethal concentration experiment and exposure were performed according to Vasconcellos and Amorim [20], as recommended by the World Health Organization [23] and Mott [14]. Ten snails of each group were separated to count hemocytes in the hemolymph and five snails of the same groups were used for histological analysis. B. glabrata hemolymph samples were carefully collected from all snails by cardiac puncture using a $1 \mathrm{ml}$ syringe equipped with a $27.5 \mathrm{G} \times 1 / 2$ " needle. The collection was conducted 24 hours after exposure to E. milii latex. The hemolymph of the snails of each group was transferred to different microtubes and kept in an ice bath during collection. For cell counting, $10 \mu$ of the hemolymph was diluted (1:1) in saline buffer (18 $\mathrm{g} \mathrm{L}^{-1}$ D-glucose, $12.2 \mathrm{~g} \mathrm{~L}^{-1} \mathrm{KCl}, 0.6 \mathrm{gL}^{-1} \mathrm{NaHCo}, 380 \mathrm{mOsm}, \mathrm{pH}$ 7.8) [24]. The number of total circulating hemocytes was determined by direct observation in a hemocytometer chamber by phase-contrast optical microscopy [25]. The hemocytes were characterized according to Cavalcanti et al. [26]. For histological analysis of snails, the shells were removed, and the viscera incubated with $10 \%$ Millonig formalin for 24 hours. The material was dehydrated with increasing concentrations of ethanol, cleared with xylol and embedded in liquid paraffin $\left(60^{\circ} \mathrm{C}\right)$ according to Tolosa et al. [27]. Paraffin inclusion, longitudinal sectioning and hematoxylin-eosin staining were performed as described by Faro et al. [28].

The effects of latex exposure and/or infection were analyzed by one-way ANOVA. Data are reported as mean \pm standard error (SE). Differences among groups were considered statistically significant when $\mathrm{P} \leq$ 0.05. Probability levels are specified in the text and figure legends. All analyses were carried out with the Prism 5.0 statistical software.

\section{Results}

Snail mortality was verified after exposure to $1.0 \mathrm{mg} / \mathrm{I}$ of E. milii latex for 24 hours. In the uninfected snails exposed to latex (E), the survival rate was $88.5 \%$. For snails infected with $\mathrm{S}$. mansoni and exposed to latex (IE), the survival rate was $66.6 \%$. No death was observed in the unexposed groups (C and I). The histological analysis of B. glabrata exposed to E. milii latex revealed tissue changes. Figures 1 and 2 show the tissue changes in groups IE (infected and exposed) and E (uninfected snails exposed), respectively. Figure $1 \mathrm{~A}$ shows the kidney and mantle region of the infected but unexposed snails (group I), with intense parasitism, hemocyte proliferation, without hemocyte reaction and no granulomatous 
reaction in the tissues analyzed. In the IE group, tissues can be seen in Figs. 1B, 1C and 1D. The exposure to $\mathrm{E}$. milii latex in infected snails stimulated the proliferation of hemocytes in different tissues: tentacle, kidney (Fig. 1B), digestive gland (Fig. 1C), mantle (Fig. 1D), and ovotestis, while exposure decreased the number of parasites, with slight tissue reaction when compared to group I in all tissues analyzed.

In the kidney and digestive gland of the IE group (Fig. 1B, 1C), fewer parasites can be seen gut, with intense cell reaction around the sporocysts and presence of a granulomatous reaction (like), while in group I (infected and unexposed), the tissue is intensely parasitized (Fig. 1A), with the presence of both primary and secondary sporocysts. In the mantle of IE group, it is possible to observe tissue destruction, presence of many hemocytes and tissue injury in the sporocysts (Fig. 1D). The subsequent Fig. 2 show the tissue change in snails of the group exposed and uninfected (E), with the presence hemocytes in the kidney (Fig. 2B), digestive gland (Fig. 2C) and mantle (Fig. 2D), causing small changes in these tissues. In the mantle region (Fig. 2D), changes occurred in the basement membrane (it is thin and translucent, which is not common). The mantle tissue presents a large edema in the basement membrane, which can be observed in detail in Fig. 2D. In the digestive gland (Fig. 2C), the epithelial cells are more elongated and larger. Tissue integrity can be seen in Fig. 2A in the control group. This tissue has an epithelium of the mucosa type, simple and cylindrical, with core in basal position and with hepatic ducts typical of normal tissue. No hemocytes and no tissue damage are present.

Besides the tissue hemocytes, the number of circulating hemocytes in B. glabrata of the different groups were counted and characterized (Fig. 3). The number of circulating hemocytes in the group infected and exposed to $1.0 \mathrm{mg} / \mathrm{l}$ of latex (IE) was significantly higher than the other groups (C, E and I). There was a significant reduction of circulating hemocytes in the infected and unexposed group (I) compared to the control group (C). In addition, the number of hemocytes in the S. mansoni infected group (I) was significantly lower compared to the IE group. No significant differences were observed in the number of circulating hemocytes between the uninfected (E) and control (C) groups. The percentage of hyalinocytes, granulocytes and other types of hemocytes circulating in the hemolymph (blast-like cells) of B. glabrata was measured 24 hours after exposure to E. milii latex. High levels of hyalinocytes were observed in all tested groups $(C=59.8 \%, E=47.5 \%, I=45.7 \%, I E=41.3 \%)$. The granulocytes were the second major hemocyte type observed in the hemolymph $(E=28.4 \%, I=36.8 \%$, IE $=31.7 \%)$, except in the control group (C), with $27.5 \%$ blast cells, followed by $12.5 \%$ granulocytes. No significant differences were encountered among the cell types and the different groups analyzed after 24 hours. We also observed a significant difference between the number of hyalinocytes and blast-like cells in both the control $(C)(P \leq 0.0354)$ and infected $(I)(P \leq 0.0354)$ groups.

\section{Discussion}

Reports of changes in snails' cellular and humoral immune responses following exposure to pesticides are rare in literature, and we found no studies using phytochemical products. Our results show, for the first time, how the exposure to a phytochemical can change the profile of hemocytes and influence the host's immune response to the parasite. In this case, we used S. mansoni-B. glabrata model with E. milii 
latex exposure. We observed proliferation of hemocytes (circulating and tissue-specific) and subsequently death of parasites in tissues with the presence of a granulomatous structure. The E. milii latex was able to influence the $\mathrm{S}$. mansoni in the intermediate host, reducing the cercariae shedding in water, changing the parasite's life cycle. The E. milii latex exposure stimulated hemocyte proliferation in the tissue after 24 hours. The presence of the product in the water may have affected sporocyst recognition as self and triggering snail response [29]. This effect caused by this phytochemical, we are calling of the schistosomostatic effect. The immunological conditions observed in our study resembled those described in the literature for infection-resistant strains, especially the cell immune response with granuloma formation, which is characteristic of resistant strains [29,30]. Therefore, our results agree with studies that have shown that several classes of stressors increase hemocyte proliferation in the tissue of B. glabrata, such as ferritin, synthetic latex and bacteria [31].

In the susceptible snails, the hemocytes presented low number, motility, phagocytic capacity and activation of new hemocytes, allowing the development of the parasite [32,33], as observed in the Group I. Compatibility between S. mansoni and B. glabrata is directly related to the incorporation of soluble antigens present in the hemolymph by the primary sporocysts, $[11,29]$ a similar reaction to that observed in vertebrate hosts, called antigenic mimicry. The suppression of the cellular immune response is an adaptative process of the parasite [11]. In our study it seems to us that the product somehow interfered in this process and further studies are needed.

In relation to characterization of the hemocytes, recently Cavalcanti et al. [26] studied the morphology B. glabrata hemocytes and observed three cell types: blast-like cells, granulocytes and hyalinocytes, the last divided into three subtypes. The hyalinocytes were the most frequent cell type, followed by granulocytes and blast cells. In the present study, hyalinocytes were most commonly found, followed by granulocytes and blast cells, except in the Group C, where the percentage of hyalinocytes was followed by blast-like cells and granulocytes, like observed by Cavalcanti et al. [26]. Those authors did not report the relation between the type of hemocytes and susceptibility of the parasite. It seems that the hemocyte type does not influence the cellular immune response, but the number of hemocytes does.

In the relation the toxic effect of phytochemicals, several works have reported snail tissue damages caused by aqueous plant extracts [34-38]. Using aqueous extract of E. milii in Lymnaea columella, Pile et al. $[37,38]$ observed lesions characterized by degeneration, necrosis and accumulation of liquid in the digestive gland and kidney in specimens submitted to $0.47 \mathrm{ml} / \mathrm{l}$ of latex, similar to our findings. We also observed lesions in the digestive gland and mantle, close to the kidney, observed by different colorations in the digestive gland and by edema in the epithelium of the kidney, suggesting liquid accumulation. In addition, we also observed dark substances without structures in the digestive gland epithelium, similar to the substances described by Adewunmi and Ogbe [34]. We observed in uninfected and infected B. glabrata the same toxic effect in the tissue described by Pile et al. [37, 38] in Lymnaea columella. In this study, using sublethal concentrations of E. milii latex, the intermediate host did not die, but the products altered the tissue structure, probably related to toxic effect of this product, which directly interfered in hemocyte profile of the tissues. 


\section{Conclusions}

Taken together, our results show that $E$. milii latex increases hemocyte proliferation and induce to the death of the parasite. This latex has a schistosomostatic effect and can be used as indirect therapy, because it can be put in the water to influence the cycle in both hosts, which makes it a promising natural product for use in endemic areas to control schistosomiasis transmission. The mechanisms of the $B$. glabrata immune response modulation by the exposure with $E$. milii latex are still poorly understood and deserve more investigation. Further studies of synergistic effects between $E$. milii latex exposure and $S$. mansoni infection on the B. glabrata immune system are under consideration.

\section{Declarations}

\section{Ethics approval and consent to participate}

This study was approved by the animal experimentation ethics committee of Oswaldo Cruz Foundation (CEUA - Fiocruz L016/2015), in accordance with the guidelines of the Brazilian Society of Laboratory Animal Science (COBEA). The study was registered with the National System for Management of Genetic Heritage and Associated Traditional Knowledge (SisGen) under number A9666E5.

\section{Consent for publication}

All authors of the manuscript have read and agreed to its content and are accountable for all aspects of the accuracy and integrity of the manuscript in accordance with ICMJE criteria.

\section{Availability of data and materials section}

The datasets used and/or analysed during the current study are available from the corresponding author on reasonable request.

\section{Competing interests}

The authors declare that they have no competing interests.

\section{Funding}

This study was funded by Coordenação de Aperfeiçoamento de Pessoal de Ensino Superior - Brasil (CAPES) - Finance code 001; Conselho Nacional de Desenvolvimento Cientifico e Tecnológico (CNPq); Fundação de Amparo à Pesquisa do Estado do Rio de Janeiro (FAPERJ- Bolsista nota 10 program) and Fundação Oswaldo Cruz (PAEF IOC-008 FIO-04).

\section{Authors' contributions}

GF, PSG and CCMS conceived and designed the study. GF, MF and VAC performed the experiments. EM, MJF, SS performed the histological analysis. CCMS revised the manuscript. All authors wrote the paper 
and approved the final version of the manuscript. This study is part of the Master dissertation of Gabriela Friani at the Postgraduate course in Ciências Veterinárias at Universidade Federal Rural do Rio de Janeiro.

\section{Acknowledgements}

We thank Schistosomiasis Laboratory/ ENSP/ Fiocruz for snails.

\section{References}

1. Colley DG, Bustinduy AL, Secor WE, King CH. Human schistosomiasis. Lancet. 2014; doi: 10.1016 / S0140-6736(13)61949-2.

2. Lu XT, Gu QY, Limpanont L, Song LG, Wu ZD, Kamolnetr O, Lv ZY. Snail borne parasitic diseases: an update on global epidemiological distribution, transmission interruption and control methods. Infec Disease. 2018; doi: 10.1186 / s40249-556 018-0414-7.

3. World Health Organization (WHO). Schistosomiasis. http://www.who.int/mediacentre/factsheets/fs115/en/ (2017). Accessed 15 Dez 2019.

4. World Health Organization (WHO)/Department of control of neglected tropical diseases. Schistosomiasis. https://www.who.int/schistosomiasis/en (2018). Accessed 20 Dez 2019.

5. Scholte RG, Carvalho OS, Malone JB, Utzinger J, Vounatsou P. Spatial distribution of Biomphalaria spp., the intermediate host snails of Schistosoma mansoni, in Brazil. Geospat Health. 2012; doi: 10.4081 / gh.2012.127.

6. Mitta G, Gourbal B, Grunau C, Knight M, Bridger JM, Théron A. The compatibility between Biomphalaria glabrata snails and Schistosoma mansoni: na increasingly complex puzzle. Adv Parasitol. 2017; doi: 10.1016 / bs.apar.2016.08.006.

7. Zänker KS. Immunology of Invertebrates: Humoral. In: Encyclopedia of Life Sciences. John Wiley \& Sons, Ltd: Chichester. 2010; doi: 10.1002/9780470015902.a0000522.pub2.

8. Pinaud S, Portet A, Allienne JF, Belmudes L, Saint-Beat C, Arancibia N, Galinier R, Du Pasquier L, Duval D, Gourbaul B. Molecular characterisation of immunological memory following homologous or heterologous challenges in the schistosomiasis vector snail, Biomphalaria glabrata. Dev Comp Immunol. 2019; doi: 10.1016 / j.dci.2018.12.001.

9. Cavalcanti MG, Filho FC, Mendonça AM, Duarte GR, Barbosa CC, De Castro CM, et al. Morphological caracterization of haemocytes from Biomphalaria glabrata and Biomphalaria straminea. Micron. 2012; doi: 10.1016 / j.micron.2011.09.002.

10. Pereira CA, Martins-Souza RL, Corrêa Jr, Coelho PM, Negrão-Corrêa D. Participation of cell-free haemolymph of Biomphalaria tenagophila in the defence mechanism against Schistosoma mansoni sporocysts. Parasite Immunol. 2008; doi: 10.1111 / j.1365-3024.2008.01062.x.

11. Prokhorova EE, Serebryakova MK, Tokmakova AS, Ataev GL. Hemocytes of mollusc Biomphalaria glabrata (Gastropoda, Pulmonata). I S J. 2018; 15, 346-51. 
12. Allienne JF, Théron A, Gourbal B.Recovery of primary sporocysts in vivo in the Schistosoma mansoni/ Biomphalaria glabrata model using a simple fixation method suitable for extraction of genomic DNA and RNA. Exp Parasitol. 2011; doi: 10.1016 / j.exppara.2011.06.003.

13. Rowle, AF, Powell A. Invertebrate immune systems specific, quasi-specific, or nonspecific. J Immunol. 2007; doi: 10.4049 / jimmunol.179.11.7209.

14. Mott K. Plant molusccides, UNDP/World Bank/WHO, John Wiley and Sons Ltda, 1987.

15. World Health Organization. Report of the who strategic and technical advisory group for neglected tropical diseases. Salle B, WHO headquarters, Geneva, Switzerland, 2014.

16. Mello-Silva CC, Vilar MG, Vasconcellos MC, Pinheiro J, Rodrigues, MLA. Carbohydrate metabolism alterations in Biomphalaria glabrata infected with Schistosoma mansoni and exposed to Euphorbia splendens var. hislopii latex. Mem Inst Oswaldo Cruz. 2010; doi: 10.1590 / S007402762010000400024.

17. Mello-Silva CC, Vasconcellos MC, Bezerra JCB, Rodrigues MLA, Pinheiro J. The influence of exposure to Euphorbia splendens var. hislopii latex on the concentrations of total proteins and nitrogen products in Biomphalaria glabrata infected with Schistosoma mansoni. Acta Trop. 2011; doi: 10.1016 / j.actatropica.2010.10.007.

18. Lima MG, Augusto RC, Vasconcellos MC, Mello-Silva CC, Pinheiro J. Metabolic changes in Biomphalaria glabrata infected with Schistosoma mansoni exposed to latex of Euphorbia milii solution versus times of preparation. J Nat Prod. 2012; 5: 222-32.

19. Augusto RC, Friani G, Vasconcellos MC, Rodrigues MLA, Mello-Silva CC. Schistosoma mansoni: Phytochemical effect on aquatic life cycle. Open J Vet Med. 2015; doi: 10.4236 / ojvm.2015.56017.

20. Vasconcellos MC, Amorin A. Molluscicidal action of the latex of Euphorbia splendens var. hislopii N.E.B. (“Crist's Crown”) (Euphorbiaceae) against Lymnaea columella (Say, 1817) (Pulmonata: Lymnaeidae), intermediate host of Fasciola hepatica Linnaeus, 1758 (Trematoda: Fasciolidae). Mem Inst Oswaldo Cruz. 2003; doi: 10.1590 / S0074-02762003000400025.

21. Brasil. Ministério da Saúde. Secretaria de Vigilância em Saúde. Departamento de Vigilância Epidemiológica. Vigilância e controle de moluscos de importância epidemiológica: diretrizes técnicas: Programa de Vigilância e Controle de Esquistossomose (PCE). $2^{\mathrm{a}}$ ed. Brasília: Editora do Ministério da Saúde; 2008.

22. Fernandez MA, Thiengo SC. Susceptibility of Biomphalaria amazonica and Biomphalaria occidentalis from Manso Dam, Mato Grosso, Brazil to infection with three strains of Schistosoma mansoni. Mem Inst Oswaldo Cruz. 2006; 101 Suppl I: 235-7.

23. World Health Organization. Report of a scientific working group on plant molluscicide and guidelines for evaluation of plant molluscicide. Geneva: World Health Organization; 1983.

24. Whitten MM, Mello CB, Gomes SA, Nigam Y, Azambuja P, Garcia ES, Ratcliffe NA. Role of superoxide and reactive nitrogen intermediates in Rhodnius prolixus (Reduviidae)/Trypanosoma rangeli interactions. Exp Parasitol. 2001; doi: 10.1006 / expr.2001.4615. 
25. Souza SS, Andrade ZA. The significance of the amoebocyte-producing organ in Biomphalaria glabrata. Mem Inst Oswaldo Cruz. 2012; doi: 10.1590 / S0074-02762012000500005

26. Cavalcanti MG, Mendonça AM, Duarte GR, Barbosa CC, De Castro CM, Alves LC, Brayner FA. Morphological caracterization of haemocytes from Biomphalaria glabrata and Biomphalaria straminea. Micron. 2012; doi: 10.1016 / j.micron.2011.09.002.

27. Tolosa EMS, Rodrigues CJ, Behmer OA. Manual de técnicas para histologia. Normal e Patológica. $2^{\mathrm{a}}$ ed. Barueri: São Paulo; 2003.

28. Faro MJ, Perazzini M, Corrêa LR, Mello-Silva CC, Pinheiro J, Mota EM, Souza S, Andrade Z, Júnior AM. Biological, biochemical and histopathological features related to parasitic castration of Biomphalaria glabrata infected by Schistosoma mansoni. Exp Parasitol. 2013; doi: 10.1016 / j.exppara.2013.03.020.

29. Augusto RC, Duval D, Grunau C. Effects of the Environment on Developmental Plasticity and Infection Success of SchistosomaParasites - An Epigenetic Perspective. Front. Microbiol. 2019; doi: $10.3389 /$ fmicb. 2019.01475

30. Fried B. An update on hemocytes in Biomphalaria snails. J Hematol Oncol Res. 2016; doi: 10.14302 / issn.2372-6601.jhor-14-401.

31. Pinaud S, Portela J, Duval D, Nowacki FC, Olive MA, Allienne JF, et al. A shift from cellular to humoral responses contributes to innate immune memmory in the vector snail Biomphalaria glabrata. PLoS Pathog. 2016; doi: 10.1371 / journal.ppat.1005361.

32. Matricon-Gondran M, Letorcart M. Internal defenses of the snail Biomphalaria glabrata: Caracterization of hemocytes and fixed phagocytes. J Inverteb Pathol. 1999; doi: 10.1006 / jipa.1999.4876.

33. Negrão-Corrêa DA, Coelho PMZ, Andrade ZAA, Martins-Souza RL, Pereira CAJ. Biomphalaria e Schistosoma mansoni: papel do sistema interno de defesa do molusco na susceptibilidade ao parasito. In: Carvalho OS, Coelho PMZ, Lenzi, HL, orgs. Schistosoma mansoni e esquistossomose: uma visão multidisciplinar. Rio de Janeiro: Editora Fiocruz, 2008. p. 485-509.

34. Adewunmi CO, Ogbe MG. The histopathology of Tetrapleura tetraptera extract on some fresh water snails. Fitoterapia. 1986; 5: 571-4.

35. Araújo SM. Alterações histológicas em Lymnaea columella provocadas pelo látex de Euphorbia splendens var. hislopii. Braz J Vet Res Anim Sci. 2002; doi: 10.1590 / S1413-95962002000300009.

36. Bode AU, Adewunmi CO, Dorfler G, Becker W. The effects of extracts from Tretapleura Tetraptera (Taub.) and Bayluscide ${ }^{\circledR}$ on cells and tissue structures of Biomphalaria glabrata (Say). J Ethnopharmacol. 1996; doi: 10.1016 / 0378-8741(95)01341-5.

37. Pile E, Coelho B, Santos JAA. Alteraciones histopatologicas em Lymnaea columella (PULMONATA: LYMNAEIDAE), huesped intermediario de Fasciola hepatica (LINNEAEUS, 1758) (TREMATODA: FASCIOLIDAE), causadas por Euphorbia splendens var. hilopii N.E.B. Parasitología al dia. 1998; 22: 105-7. doi: 10.4067 / S0716-07201998000300009. 
38. Pile E, Pastor N, Santos JAA, Barros JSL. Aspectos histopatológicos de Biomphalaria glabrata Say, 1817, hospedeiro intermediário de Schistosoma mansoni, submetida a Niclosamida. Braz J Vet Res Anim Sci. 2002; 39: 218-9.

\section{Figures}

\section{Figure 1}

A: Group I "S. mansoni-infected and unexposed" kidney and mantle region with presence of sporocysts ${ }^{*}$ ) and tissue hemocytes (arrows) (magnification $100 \times$ ). B: Group IE "S. mansoni-infected and exposed to E. milii latex", kidney region presence of the dense infiltrate of hemocytes (arrows) and granulomatous type reaction (circles), both around sporocysts (magnification $100 \times$ ). C: Group IE "S. mansoni-infected and exposed to E. milii latex" digestive gland with the same results of the kidney (magnification $100 \times$ ). D: Group IE "S. mansoni-infected and exposed to E. milii latex" mantle region, with accumulation of hemocytes, destruction of the parasites (circle) (magnification $100 \times$ ). All sections stained with hematoxylin e eosin. Magnification 100X.

\section{Figure 2}

A: Group C "uninfected and unexposed Biomphalaria glabrata", digestive gland no changes (magnification $100 \times$ ). B: Group E "uninfected and exposed to E. milii", kidney region with presence of hemocytes (arrow) (magnification $100 \times$ ). C: Group E "uninfected and exposed to E. milii", digestive gland with more hemocytes present in the tissue (arrow) (magnification $200 \times$ ). D: Group E "uninfected and exposed to E. milii", mantle region with edemas ${ }^{*}$ ) and few hemocytes by tissue (arrow) (magnification $100 \times)$. All sections stained with hematoxylin e eosin. 


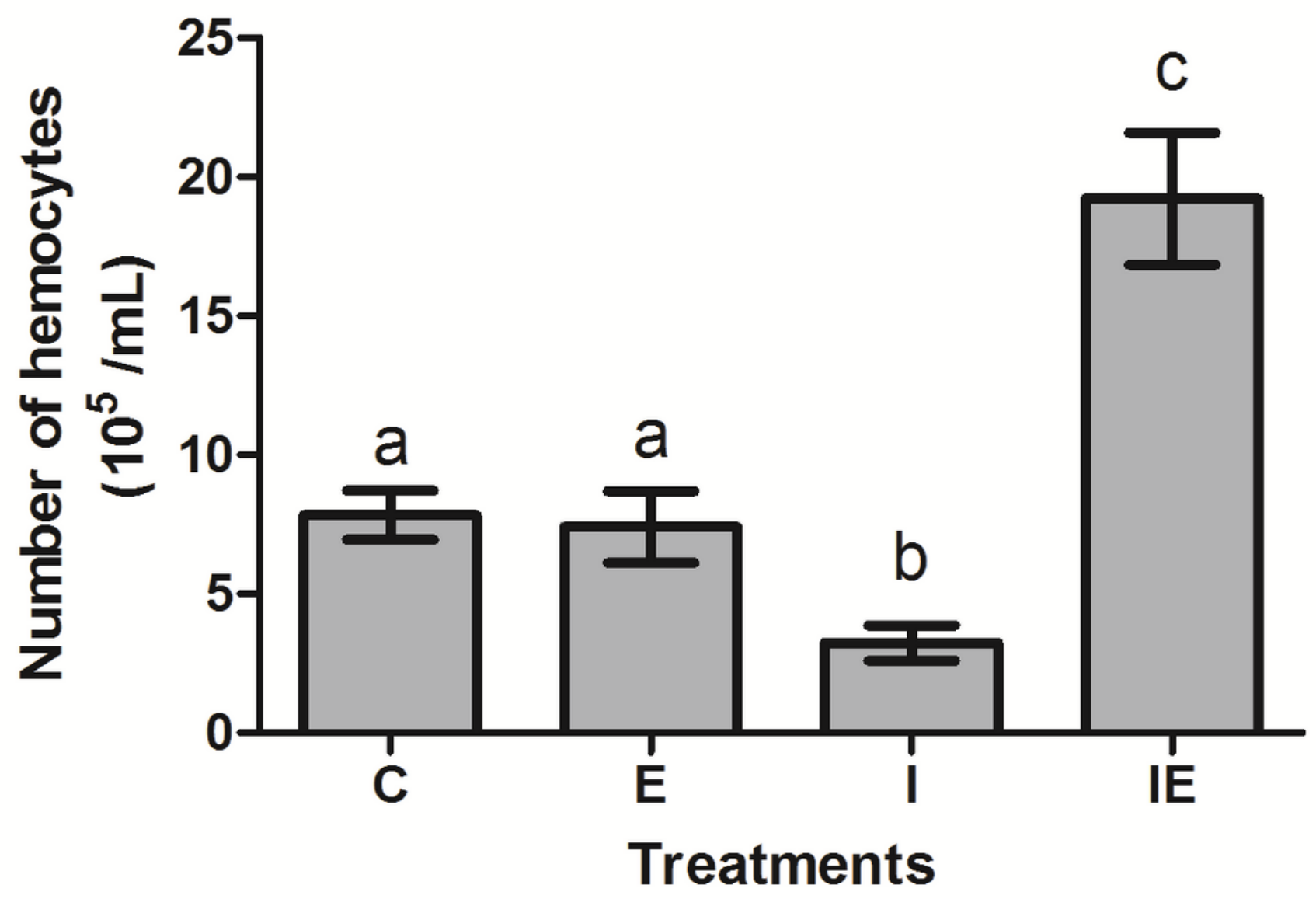

Figure 3

Effects of the Euphorbia milii latex exposure in the number of total circulating hemocytes in the uninfected and infected Biomphalaria glabrata by Schistosoma mansoni hemolymph.

\section{Supplementary Files}

This is a list of supplementary files associated with this preprint. Click to download.

- GraphicalAbstract.png

- GraphicalAbstract.png 